\title{
KEBIJAKAN PENETAPAN BITUNG SEBAGAI KAWASAN EKONOMI KHUSUS (KEK)
}

\section{THE POLICY OF ASSIGNING BITUNG AS A SPECIAL ECONOMIC ZONE (SEZ)}

\author{
Radityo Pramoda dan Tenny Apriliani \\ Pusat Penelitian Sosial Ekonomi Kelautan dan Perikanan \\ Gedung Balitbang KP. I, Komplek Bina Samudera \\ Jl. Pasir Putih I Ancol Timur, Jakarta-14430 \\ Email: radityopramoda@yahoo.com, apriliani.tenny@gmail.com
}

Naskah diterima: 23 Juni 2015, revisi pertama: 20 April 2016, revisi kedua: 18 Juli 2016.

\begin{abstract}
The Bitung Special Economic Zone (SEZ) is a regional development policy specially devised to drive economic growth based on well-set-up infrastructures, and incentives. The role of central government in supervising the policy is very important in coping with each negative impact, both economic as well as social. The sole purpose of this qualitative research is to study the implementation of the regional development policy of Bitung as a Special Economic Zone. The analysis had been carried out with a case study approach, and then descriptively elaborated, and resulted in the finding of: (1) the previous development and infrastructure blueprint at the Bitung City level have so far been in line with the SEZ; (2) the SEZ has so far been attracting industry-based investment and creating work for the labors; (3) the formulated local regulations have been considered enough in giving legal security toward investment; (4) the establishment of Bitung as an SEZ has been considered as a sound strategic policy; and (5) the readiness of Bitung as an SEZ has been deemed adequate, despite the facts that it still needed minor adjustments in a few aspects, such as: better socialization, acceleration of land relinquishment, and increasing electricity/power.
\end{abstract}

Keywords: Policy, Bitung Determination, Special Economic Zone (SEZ).

\begin{abstract}
Abstrak
Kawasan Ekonomi Khusus (KEK) Bitung merupakan kebijakan pengembangan wilayah dalam mendorong pertumbuhan ekonomi yang didukung infrastruktur berkualitas, serta pemberian kemudahan (insentif). Fungsi pemerintah pusat mengawal KEK Bitung, sangat penting untuk mencegah timbulnya dampak negatif secara ekonomi dan sosial. Penelitian kualitatif ini bertujuan untuk mengkaji
\end{abstract}


implementasi pembangunan ekonomi dan penetapan kebijakan Bitung sebagai KEK. Analisis kajian dilakukan menggunakan pendekatan studi kasus, yang dipaparkan secara deskriptif. Hasil penelitian menunjukkan: (1) pembangunan yang telah ada maupun pengembangan rencana infrastruktur pada kawasan Kota Bitung sudah mendukung KEK; (2) KEK Bitung telah menciptakan investasi berbasis industri dan penyerapan tenaga kerja; (3) regulasi lokal yang dibentuk sudah memberikan kepastian hukum kepada investor; (4) Penetapan KEK Bitung merupakan kebijakan strategis pemerintah yang tepat; (5) kesiapan Bitung menjadi KEK secara umum sudah memadai, tetapi masih perlu untuk melaksanakan: sosialisasi kepada masyarakat, percepatan eksekusi pembebasan lahan, dan penambahan daya listrik.

Kata kunci: Kebijakan, Penetapan Bitung, Kawasan Ekonomi Khusus (KEK).

\section{A. PENDAHULUAN}

Indonesia secara geografis terletak di jantung pertumbuhan ekonomi dunia dan tidak terlepas dalam dinamika globalisasi (Kementerian Koordinator Bidang Perekonomian, 2011:13). Dinamika globalisasi yang terjadi saat ini menyebabkan Indonesia bertekad melaksanakan transformasi, serta pertumbuhan ekonomi untuk mencapai visi negara maju sejahtera pada tahun 2025. Pertumbuhan ekonomi yang tinggi dan berkelanjutan merupakan keharusan bagi kelangsungan pembangunan, serta kesejahteraan (Tambunan, 2012:40). Konsep kesejahteraan dijabarkan pemerintah dengan menciptakan kawasan baru, yaitu melakukan percepatan dan perluasan pembangunan ekonomi. Pembangunan ekonomi diartikan sebagai pengembangan wilayah untuk memberdayakan basis potensi kawasan yang dimiliki secara berkelanjutan, terpadu, serta kompetitif.

Kebijakan utama yang diambil pemerintah yakni menerbitkan Undang-Undang Nomor 39 Tahun 2009, tentang Kawasan Ekonomi Khusus/KEK (UU No. 39/2009). Lahirnya UU No. 39/2009, didasari adanya kebutuhan mempercepat pembangunan sebuah kawasan dan menjaga keseimbangan kemajuan suatu daerah (sebagai kesatuan ekonomi nasional). Terminologi KEK menurut UU No. 39/2009:

"Kawasan dengan batas tertentu dalam wilayah hukum Negara Kesatuan Republik Indonesia yang ditetapkan untuk menyelenggarakan fungsi perekonomian dan memperoleh fasilitas tertentu".

Pemberian fasilitas tertentu atau perlakuan khusus, dimaksudkan agar dunia usaha memiliki perspektif jangka panjang.

Daerah yang ditetapkan pemerintah mendapatkan fasilitas tertentu pada tahun 2014, adalah Bitung yang terletak di Provinsi Sulawesi Utara. KEK Bitung dibentuk melalui Peraturan Pemerintah Nomor 32 Tahun 2014, tentang Kawasan Ekonomi Khusus Bitung (PP No. 32/ 2014). Sasaran kebijakan KEK Bitung ialah mewujudkan lingkungan yang kondusif bagi peningkatan aktivitas investasi, ekspor, dan perdagangan. Kebijakan peningkatan daya pertumbuhan ekonomi KEK Bitung di satu sisi memerlukan proses yang kompleks dan multidimensional, sedangkan pada sisi yang lain pemerintah mengharapkan implementasinya dapat diselesaikan sesuai target yang direncanakan. Kondisi inilah yang menyebabkan lahirnya Keputusan Menteri Koordinator Bidang Perekonomian Selaku Ketua Harian Komite Percepatan dan Perluasan Pembangunan Ekonomi Indonesia Nomor 60 Tahun 2013, tentang 
Tim Kerja pada Komite Percepatan dan Perluasan Pembangunan Ekonomi Indonesia 20112025 (Kepmenko No. 60/2013).

Penerbitan Kepmenko No. 60/2013, dimaksudkan untuk membentuk tim yang bertanggung jawab terhadap kelancaran proses pembangunan ekonomi pada setiap koridor/ wilayah yang telah ditetapkan. Ketua tim kerja koridor ekonomi Sulawesi menurut Kepmenko No. 60/2013, adalah Menteri Kelautan dan Perikanan. Tugas tim kerja koridor Sulawesi meliputi: (1) melakukan koordinasi pelaksanaan, (2) mengidentifikasi permasalahan dan hambatan, (3) melakukan pemantauan dan evaluasi, (4) melaksanakan sinkronisasi kebijakan pemerintah pusat dengan pemerintah daerah (Pemda), (5) menyiapkan rekomendasi kebijakan dan langkah strategis. Salah satu daerah pembangunan ekonomi yang menjadi perhatian tim kerja koridor Sulawesi, yaitu program KEK Bitung. Penelitian ini merupakan tindak lanjut disahkannya Kepmenko No. 60/2013, sebagai upaya melaksanakan mandat sebagai tim kerja koridor Sulawesi. Berdasarkan hal tersebut, tujuan kajiannya difokuskan membahas implementasi pembangunan ekonomi di wilayah Bitung dalam mendukung kebijakan pemerintah yang telah menetapkannya sebagai KEK.

\section{B. METODOLOGI}

\section{Lokasi dan Waktu}

Penelitian ini dilaksanakan di Bitung (Sulawesi Utara), pada tahun 2014. Bitung dipilih menjadi lokasi penelitian, karena merupakan daerah yang mendapatkan mandat sebagai wilayah KEK berdasarkan PP No. 32/2014. Bitung merupakan kota potensial yang terletak pada koridor ekonomi Sulawesi, serta memiliki posisi geografis $1^{\circ} 23^{\prime} 23^{\prime \prime}-1^{\circ} 35^{\prime} 39^{\prime \prime}$ LU dan 1251'43"12518’13" BT. Batas wilayah administratif Bitung:

- Utara : Kecamatan Likupang (Kabupaten Minahasa) dan Laut Maluku

- Timur : Selat Lembeh

- Selatan : Laut Maluku dan Samudera Pasifik

- $\quad$ Barat : Kecamatan Kauditan (Kabupaten Minahasa)

Kota Bitung memiliki luas 30.400 Ha, yang meliputi kecamatan: Bitung Selatan (5.040 Ha); Bitung Tengah (2.438 Ha); Bitung Barat (3.374 Ha); Bitung Timur (5.908 Ha); dan Bitung Utara (13.640 Ha). Menurut lampiran II, Peraturan Daerah Kota Bitung Nomor 11 Tahun 2013, tentang Rencana Tata Ruang Wilayah Kota Bitung Tahun 2013-2033:

"Kota Bitung dibentuk pada tahun 1990 berdasarkan UU Nomor 7 Tahun 1990, tentang Pembentukan Kotamadya Daerah Tingkat II Bitung (sebelumnya Bitung merupakan kota administratif bagian Kabupaten Daerah Tingkat II Minahasa). Pada tanggal 6 Desember 1995, terbentuklah Kecamatan Bitung Timur (hasil pemekaran Kecamatan Bitung Tengah) yang menjadikan Kotamadya Bitung memiliki 4 wilayah kecamatan. Memasuki era otonomi daerah, Bitung menjadi kota dan bukan lagi kotamadya. Pada tanggal 14 Desember 2001, berdasarkan Surat Keputusan Walikota Bitung Nomor 100 Tahun 2001, Kecamatan Bitung Tengah mengalami pemekaran menjadi dua kecamatan, yaitu Kecamatan Bitung Tengah dan Kecamatan Bitung Barat (jumlah kecamatan di Kota Bitung menjadi 5). Jumlah kelurahan juga mengalami pemekaran menjadi 60 kelurahan (sebelumnya 44 kelurahan). Pada tanggal 10 Oktober 2007, Kota Bitung mengalami pemekaran menjadi 8 kecamatan dan 69 kelurahan". 


\section{Data dan Sumber Data}

Pengumpulan data primer dilakukan melalui wawancara yang terfokus (focused interview) dan wawancara mendalam (depth interview), kepada informan kunci yang mengetahui tentang KEK Bitung secara utuh. Informan kunci penelitian ini: pejabat Badan Perencanaan dan Pembangunan Daerah (BAPPEDA) Provinsi Sulawesi Utara dan Bitung; pejabat Badan Koordinasi Penanaman Modal (BKPM) Provinsi Sulawesi Utara; pejabat Badan Pelayanan Perizinan Terpadu dan Penanaman Modal Daerah (BPPTPMD) Bitung; pejabat Pelabuhan Perikanan Samudera (PPS) Bitung; pejabat Pemerintah Provinsi (Pemprov) Sulawesi Utara dan Pemerintah Kota (Pemkot) Bitung; pelaku usaha; serta masyarakat. Data sekunder ditelusuri menggunakan teknik studi literatur yang mengkaji tentang KEK (khususnya Bitung). Studi literatur diperlukan untuk menambah informasi, melengkapi referensi bahan rujukan, dan memperkuat pembahasan penelitian.

\section{Metode Penelitian}

Penelitian kualitatif ini menggunakan pendekatan studi kasus dan dijabarkan dengan metode deskriptif. Menurut Yin (2009:4), pendekatan studi kasus yang dilakukan untuk mengkaji topik pembahasan penelitian dapat memberikan nilai tambah secara unik tentang fenomena sosial dan politik. Tujuan pemilihan pendekatan studi kasus dan metode deskriptif adalah menggambarkan pengelolaan pembangunan KEK dan investasi di Bitung, menjelaskan kewenangan/regulasi yang mendukung KEK Bitung, memotret permasalahan yang dihadapi Bitung (wilayah KEK), serta memahami kesiapan pelaksanaan pengembangan KEK Bitung. Materi penelitian yang dibahas: (1) Kebijakan Kawasan Ekonomi Khusus; (2) Pembangunan Infrastruktur Kawasan Ekonomi Khusus Bitung; (3) Perkembangan Investasi Bitung; (4) Kebijakan Lokal Kawasan Ekonomi Khusus Bitung; (5) Kesiapan Bitung sebagai Kawasan Ekonomi Khusus. Hasil analisis data yang diperoleh, merupakan acuan untuk mengkaji kebijakan penetapan KEK Bitung. Keluaran akhir penelitian ini dirumuskan menjadi rekomendasi bagi pemerintah, sebagai alternatif pemikiran atau tambahan kebijakan dalam mengatur pembangunan KEK Bitung ke arah yang lebih baik.

\section{Tinjauan Teoritis}

Keunggulan setiap negara semakin ditentukan oleh kemampuan negara tersebut mengembangkan kebijakan-kebijakan publik yang baik (Nugroho, 2011:24). Pada tataran ini pemerintah dituntut membuat kebijakan publik yang unggul (berdaya saing) sebagai upaya mencapai target pembangunan, menyelesaikan permasalahan, dan acuan strategis pemenuhan tujuan. Kebijakan publik menentukan bentuk suatu kehidupan setiap bangsa dan merupakan domain negara atau pemerintahan. Terminologi kebijakan publik adalah segala sesuatu yang dikerjakan pemerintah, mengapa mereka melakukan, dan hasil yang membuat sebuah kehidupan bersama tampil berbeda (Dye, 1995:5). Kebijakan publik adalah keputusan yang mengikat bagi orang banyak pada tataran strategis atau bersifat garis besar yang dibuat oleh pemegang otoritas publik. Sebagai keputusan yang mengikat, maka kebijakan publik haruslah dibuat oleh otoritas politik (yakni mereka yang menerima mandat dari publik dan umumnya melalui suatu proses pemilihan untuk bertindak atas nama rakyat) (Suharto,2008:1).

Kebijakan negara selalu mempunyai tujuan tertentu atau merupakan tindakan yang berorientasi kepada tujuan (Madani, 2011:16). Penelitian Enceng dan Madya (2014) yang mengkaji evaluasi perumusan, implementasi, dan lingkungan kebijakan, menyebutkan bahwa 
pemerintah sebagai pelaksana kebijakan harus menterjemahkan cara atau aksi yang harus dilakukan untuk mencapai tujuan kebijakan. Cara atau aksi yang dilakukan oleh pemerintah tersebut, dikenal dengan implementasi kebijakan. Penelitian Akib (2010) tentang implementasi kebijakan (apa, mengapa, dan bagaimana), menjelaskan bahwa pada prinsipnya setiap kebijakan publik selalu ditindaklanjuti dengan implementasi kebijakan. Kebijakan publik yang memiliki nilai demokratis, hasilnya akan mempunyai basis yang kuat dan mudah diimplementasikan. Mengacu hal tersebut, untuk menciptakan kebijakan yang efektif sedikitnya diperlukan: (1) adanya perangkat hukum berupa peraturan perundang-undangan, sehingga dapat diketahui publik apa yang telah diputuskan; (2) kebijakan harus mempunyai mempunyai kejelasan struktur pelaksana dan pembiayaannya; (3) adanya kontrol publik (mekanisme yang memungkinkan publik mengetahui, apakah kebijakan ini dalam pelaksanaannya mengalami penyimpangan atau tidak) (Suharto, 2008:2).

Pembuatan kebijakan KEK kewenangannya melekat pada domain negara/pemerintah dan merupakan manifestasi pengaturan wilayah. Pemerintah menjanjikan bahwa daerah yang ditetapkan menjadi KEK, akan diberikan insentif tertentu (Tabel 1) untuk menarik investor. Kebijakan KEK memiliki konsekuensi adanya pemberian insentif dalam mendukung kemudahan investasi. Insentif yang diberikan meliputi kebijakan yang terkait dengan: sistem maupun tarif pajak; bea masuk; aturan ketenagakerjaan; perizinan; pertanahan; dan lainnya (sesuai kesepakatan dengan dunia usaha). Penelitian yang dilakukan Hasim Purba (2006) menyatakan, bahwa program KEK membutuhkan dukungan investasi asing dalam rangka mengembangkan pembangunan ekonomi. Masuknya modal asing, menyebabkan adanya ketimpangan pembagian hasil dan cenderung merugikan negara. Pada konteks ini, pemerintah harus memperjuangkan posisi tawar untuk memperoleh manfaat keuntungan yang signifikan dan proporsional. 
Tabel 1.

Pemberian Fasilitas Insentif Wilayah KEK

\begin{tabular}{|c|c|}
\hline \multicolumn{2}{|r|}{ FASILITAS FISKAL } \\
\hline Insentif & Keterangan \\
\hline PPh (Pajak Penghasilan) & $\begin{array}{l}\text { Diberikan kepada setiap wajib pajak yang melakukan usaha di } \\
\text { KEK dan diberikan tambahan fasilitas PPh (sesuai dengan } \\
\text { karakteristik zona) }\end{array}$ \\
\hline Pajak Bumi dan Bangunan & Pengurangan sesuai ketentuan peraturan perundangan \\
\hline Bea Masuk & Penangguhan bea masuk untuk impor barang ke wilayah KEK \\
\hline Bea Cukai & $\begin{array}{l}\text { Pembebasan cukai (sepanjang barang tersebut merupakan } \\
\text { bahan baku atau bahan penolong produksi) }\end{array}$ \\
\hline PPN (Pajak Pertambahan Nilai) & Tidak dipungut untuk barang kena pajak \\
\hline $\begin{array}{l}\text { Pajak Penjualan atas Barang } \\
\text { Mewah (PPnBM) }\end{array}$ & $\begin{array}{l}\text { Tidak dipungut untuk barang kena pajak (untuk barang kena } \\
\text { pajak dapat diberikan sesuai ketentuan peraturan } \\
\text { perundangan) }\end{array}$ \\
\hline \multicolumn{2}{|r|}{ FASILITAS NON FISKAL } \\
\hline Insentif & $\begin{array}{r}\text { Keterangan } \\
\end{array}$ \\
\hline Dukungan Pemda & $\begin{array}{l}\text { - Pengurangan pajak dan restribusi daerah } \\
\text { - Komitmen untuk pengoperasian adminsitrator KEK }\end{array}$ \\
\hline $\begin{array}{l}\text { Kemudahan dan keringanan } \\
\text { imigrasi bagi orang asing pelaku } \\
\text { bisnis }\end{array}$ & e \\
\hline $\begin{array}{l}\text { Kemudahan untuk memperoleh } \\
\text { hak atas tanah dan pembebasan } \\
\text { lahan }\end{array}$ & $\begin{array}{l}\text { Bagi badan usaha yang telah memperoleh tanah di lokasi akan } \\
\text { diberikan hak atas tanah }\end{array}$ \\
\hline $\begin{array}{l}\text { Daftar negatif investasi tidak } \\
\text { diberlakukan }\end{array}$ & (Syarat ditentukan) \\
\hline Kemudahan perizinan & $\begin{array}{l}\text { - Pelayanan Terpadu Satu Pintu (PTSP) } \\
\text { - Kemudahan dan keringanan untuk bidang perizinan usaha, } \\
\text { perindustrian, perdagangan, dan kepelabuhan }\end{array}$ \\
\hline
\end{tabular}

Sumber: Fauzi (2013:4-5)

Berdasarkan Tabel 1, diketahui bahwa zona prioritas pengembangan KEK meliputi: pengolahan; logistik; industri; pengembangan teknologi; serta pariwisata dan energi, baik ekspor maupun kebutuhan dalam negeri. KEK diselenggarakan untuk menjadi stimulus terhadap: (1) peningkatan Produk Domestik Bruto dan Produk Domestik Regional Bruto (PDRB); (2) penghematan devisa; (3) penambahan lapangan kerja; (4) penambahan pendapatan pajak.

Penelitian Alkadri (2011) yang terkait dengan kebijakan pengembangan KEK di Provinsi Banten, mengemukakan faktor yang menjadi kunci sukses pembangunan KEK adalah dengan mengembangkan: industri, infrastruktur, kelembagaan, SDM, strategi promosi, dan kegiatan sosialisasi. Regulasi KEK yang diciptakan pemerintah intinya berusaha menjaga agar dunia usaha mendapatkan kepastian hukum melaksanakan kegiatan produksi, investor tertarik menanamkan modalnya, penyerapan tenaga kerja meningkat, serta pengembangan infrastruktur dapat berjalan dengan lancar. Pengembangan wilayah Bitung merupakan keterpaduan pembangunan antar-sektor, daerah, maupun masyarakat. Kajian studi kasus yang dilakukan Lingga dan Pratomo (2013) pada wilayah KEK Sei Mangkei, menunjukkan bahwa pengembangan KEK harus dibarengi dengan pembangunan kehidupan sosial dan peningkatan ekonomi masyarakat sekitarnya. Strategi kebijakan yang bisa dilakukan adalah dengan mewajibkan setiap badan usaha pada wilayah KEK, mengalokasikan anggarannya untuk 
melaksanakan bina lingkungan. Perspektif kebijakan ini harus selalu direfleksikan pada kebutuhan negara dalam jangka panjang.

\section{HASIL DAN PEMBAHASAN}

\section{Kebijakan Kawasan Ekonomi Khusus}

Indonesia memiliki kekuatan potensi yang terdiri: kekayaan alam, penduduk, letak geografis, dan sumber daya lainnya. Potensi tersebut merupakan modal yang dapat didayagunakan untuk mempercepat pertumbuhan ekonomi (Rofiq, 2014:3). Pemanfaatan potensi ekonomi harus dikelola secara kondusif, menggunakan strategi yang tepat dalam menjaga keberlanjutannya. Menurut Hidayat dan Hidayat (2010:1):

"Satu diantara model untuk menciptakan lingkungan yang kondusif bagi investasi, perdagangan, dan ekspor yang ditujukan untuk mempercepat pertumbuhan ekonomi, adalah dengan menciptakan suatu KEK (Special Economic Zone)”.

Isu seputar KEK bergulir ketika Presiden Susilo Bambang Yudhoyono menandatangani kerja sama pembentukan Special Economic Zone bersama Perdana Menteri Singapura Lee Hsien Loong di Turi Beach Resort (25 Juni 2006). Kebijakan pengaturan KEK yang terkandung dalam Pasal 31, Ayat (1), UU Nomor 25 Tahun 2007, tentang Penanaman Modal (UU No. 25/ 2007), menjadi salah satu naskah resmi rujukan lahirnya UU No. 39/2009.

Pasal 31, Ayat (1), UU No. 25/2007:

(1) Untuk mempercepat pengembangan ekonomi di wilayah tertentu yang bersifat strategis bagi pengembangan ekonomi nasional dan untuk menjaga keseimbangan kemajuan suatu daerah, dapat ditetapkan dan dikembangkan kawasan ekonomi khusus.

Isu penting kebijakan seputar KEK Bitung: (1) penyediaan jaringan infrastruktur yang memadai, administrasi-birokrasi yang sederhana, dan aturan ketenagakerjaan berstandar internasional; (2) KEK merupakan bagian yang menyatu dalam tata kelola pembangunan; (3) menumbuhkan kemitraan pemerintah dan swasta. Pengelolaan kebijakan lokal KEK Bitung sangat krusial karena pemerintah pusat hanya menetapkan norma, standar, pedoman, dan manualnya (wawancara dengan pejabat Pemkot Bitung, 27/08/2014). Menurut Syarif Hidayat dalam Hidayat dan Hidayat (2010:95), fungsi utama pemerintah (penyelenggara KEK) yaitu sebagai pelaksana, fasilitator, dan koordinasi. Fungsi tersebut mempunyai nilai penting, ketika dihadapkan pada kesejahteraan masyarakat dan tata kelola pengembangan ekonomi KEK Bitung yang tertib.

Perkembangan perekonomian Bitung sebelum ditetapkan sebagai KEK, telah memberikan kontribusi penting bagi PDRB (wawancara dengan pejabat BAPPEDA Bitung, 27/08/2014). Perkembangan ekonomi didefinisikan: (1) harus diukur dalam arti kenaikan pendapatan nasional nyata pada jangka waktu yang panjang, (2) berkaitan dengan kenaikan pendapatan nyata per kapita jangka panjang, (3) dipandang dari titik kesejahteraan ekonomi (Jhingan, 2013:5-6). Kemajuan yang cukup baik terhadap peran peningkatan perekonomian daerah tersebut, menjadi alasan utama Pemprov Sulawesi Utara menginginkan Bitung dikukuhkan sebagai KEK. Pengusulan pembentukan KEK Bitung dilakukan sesuai dengan ketentuan Pasal 4, UU No. 39/2009 dan Pasal 7, Peraturan Pemerintah Nomor 2 Tahun 2011, tentang Penyelenggaraan Kawasan Ekonomi Khusus (PP No. 2/2011), sebagaimana telah diubah dengan Peraturan Pemerintah Nomor 100 Tahun 2012, tentang Perubahan atas Peraturan Pemerintah Nomor 2 Tahun 2011 tentang Penyelenggaraan Kawasan Ekonomi Khusus (PP No. 100/2012). 
Pasal 4, UU No. 39/2009:

Lokasi yang dapat diusulkan untuk menjadi KEK harus memenuhi kriteria:

a. sesuai dengan Rencana Tata Ruang Wilayah dan tidak berpotensi mengganggu kawasan lindung;

b. pemerintah provinsi/kabupaten/kota yang bersangkutan mendukung KEK;

c. terletak pada posisi yang dekat dengan jalur perdagangan internasional atau dekat dengan jalur pelayaran internasional di Indonesia atau terletak pada wilayah potensi sumber daya unggulan; dan

d. mempunyai batas yang jelas.

Pasal 7, PP No. 2/2011 (perubahan terakhir melalui PP No. 100/2012):

Usulan lokasi KEK sebagaimana dimaksud dalam Pasal 6 harus memenuhi kriteria:

a. sesuai dengan Rencana Tata Ruang Wilayah dan tidak berpotensi mengganggu kawasan lindung;

b. adanya dukungan dari pemerintah provinsi dan/atau pemerintah kabupaten/kota yang bersangkutan;

c. terletak pada posisi yang dekat dengan jalur perdagangan internasional atau dekat dengan jalur pelayaran internasional di Indonesia atau terletak pada wilayah potensi sumber daya unggulan; dan

d. mempunyai batas yang jelas.

Pengusulan pembentukan Kawasan Ekonomi Khusus Bitung diajukan kepada Dewan Nasional Kawasan Ekonomi Khusus. Pengajuan dilengkapi dengan persyaratan pengusulan KEK Pasal 6, Ayat (2), UU No. 39/2009 dan Pasal 22, Ayat (2), PP No. 2/2011, sebagaimana telah diubah dengan PP No. 100/2012.

Pasal 6, Ayat (2), UU No. 39/2009:

(2) Usulan sebagaimana dimaksud pada ayat (1) dilengkapi persyaratan paling sedikit:

a. peta lokasi pengembangan serta luas area yang diusulkan yang terpisah dari permukiman penduduk;

b. rencana tata ruang KEK yang diusulkan dilengkapi dengan peraturan zonasi;

c. rencana dan sumber pembiayaan;

d. analisis mengenai dampak lingkungan yang sesuai dengan ketentuan peraturan perundang-undangan;

e. hasil studi kelayakan ekonomi dan finansial; dan

f. jangka waktu suatu KEK dan rencana strategis.

Pasal 22, Ayat (2), PP No. 2/2011 (perubahan terakhir melalui PP No. 100/2012):

(2) Usulan pembentukan KEK sebagaimana dimaksud pada ayat (1) dilengkapi dengan dokumen berupa:

a. deskripsi rencana pengembangan KEK yang diusulkan, paling sedikit memuat rencana dan sumber pembiayaan serta jadwal pembangunan KEK;

b. peta detail lokasi pengembangan serta luas area KEK yang diusulkan;

c. rencana peruntukan ruang pada lokasi KEKyang dilengkapi dengan peraturan zonasi;

d. studi kelayakan ekonomi dan finansial;

e. analisis mengenai dampak lingkungan hidup yang sesuai dengan ketentuan peraturan perundang-undangan;

f. usulan jangka waktu beroperasinya KEK dan rencana strategis pengembangan KEK;

g. penetapan lokasi atau bukti hak atas tanah; 
h. persetujuan dari pemerintah kabupaten/kota terkait dengan lokasi KEK yang diusulkan;

i. rekomendasi dari otoritas pengelola infrastruktur pendukung dalam hal untuk pengoperasian KEK memerlukan dukungan infrastruktur lainnya; dan

j. pernyataan kesanggupan melaksanakan pembangunan dan pengelolaan KEK.

Berdasarkan persyaratan yang sudah dilengkapi, maka Dewan Nasional KEK menyetujui pembentukan KEK Bitung dan mengajukan rekomendasi penetapannya kepada Presiden (wawancara dengan pejabat BAPPEDA Provinsi Sulawesi Utara, 30/08/2014). Ketentuan Bitung menjadi KEK disikapi pemerintah dengan menerbitkan PP No. 32/2014.

Bitung kewenangannya berada pada Pemprov Sulawesi Utara dan mempunyai luas daratan $304 \mathrm{~km}^{2}$. Zona yang dikembangkan pada KEK Bitung meliputi industri, logistik, serta pengolahan ekspor. KEK Bitung mempunyai luas 534 Ha dan terletak dalam wilayah kecamatan Matuari, Kota Bitung, Provinsi Sulawesi Utara. Batas KEK Bitung:

- Utara : Kelurahan Manembo-nembo, Kecamatan Matuari, Kota Bitung.

- Timur : Kelurahan Manembo-nembo dan Tanjung Merah, Kecamatan Matuari, serta Kota Bitung dan Selat Lembeh.

- Selatan : Kelurahan Tanjung Merah, Kecamatan Matuari, dan Kota Bitung.

- Barat $\quad$ : Kelurahan Sagerat, Kecamatan Matuari, dan Kota Bitung.

Keunggulan yang menjadi faktor kekuatan pencapaian tujuan pembangunan daerah Bitung: (1) memiliki masyarakat beragam (heterogen) yang dinamis, religius, serta menjunjung tinggi kebhinekaan/pluralisme (selalu menginginkan adanya perbaikan untuk mewujudkan masyarakat sejahtera); (2) memiliki aspek geografis dan posisi strategis yang sangat baik untuk pengembangan kota industri, serta perdagangan internasional (berbasis potensi sumber daya kelautan dan ekosistem cagar alam hutan); (3) memiliki pelabuhan laut yang alami (RKPD Kota Bitung, 2012:64).

\section{Pembangunan Infrastruktur Kawasan Ekonomi Khusus Bitung}

Pengertian infrastruktur adalah segala sesuatu yang menunjang terselenggaranya suatu proses (usaha, pembangunan, proyek, dan sebagainya) (Pusat Bahasa, 2008:586). Infrastruktur merupakan faktor penyangga sistem sosial dan sistem ekonomi, serta menjadi pondasi terbentuknya kegiatan pembangunan. Sistem sosial dan sistem ekonomi mempunyai ketergantungan pada infrastruktur, sehingga keberadaan infrastruktur yang memadai mempunyai peran mendukung keberlanjutan pembangunan (Rahayu et. al., 2013:23). Hubungan antara sistem sosial, sistem ekonomi, infrastruktur, dan lingkungan, dapat dilihat pada Gambar 1.

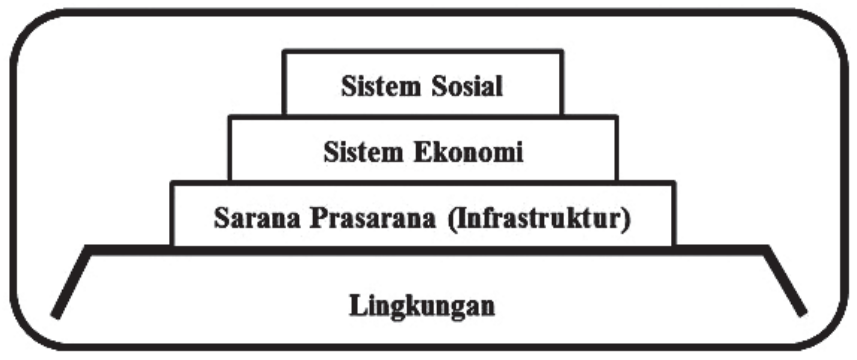

Sumber: Grigg (1998) dalam Rahayu et. al. (2013:23)

Gambar 1.

Hubungan Sistem Sosial, Ekonomi, Infrastruktur, dan Lingkungan 
Berdasarkan Gambar 1, diketahui bahwa faktor lingkungan mempunyai peran fundamental untuk menopang semua sistem. Infrastruktur ditempatkan sebagai mediator antara sistem sosial dan sistem ekonomi dalam kehidupan manusia, yang disokong oleh lingkungan. Mengingat posisinya sebagai mediator, maka kondisi infrastruktur harus tetap dijaga keharmonisannya (artinya tidak kekurangan (berdampak pada manusia) dan tidak berlebihan (tanpa memperhitungkan daya dukung lingkungan)). Kondisi infrastruktur yang tidak harmonis dampaknya akan dirasakan oleh manusia dan mahluk hidup lainnya. Mengacu kepada hal tersebut, perancangan sistem pengembangan infrastruktur wilayah KEK Bitung harus dilakukan secara terkoordinir, terpadu, dan holistik.

Wilayah Bitung dijadikan KEK karena mempunyai potensi secara geoekonomi dan geostrategis. Keunggulan potensi geoekonomi Bitung:

- Memiliki lokasi strategis sebagai pusat pertumbuhan dan distribusi barang, maupun penunjang logistik kawasan timur Indonesia.

- Mempunyai akses internasional (khususnya ke Brunei Darussalam, Indonesia, Malaysia, The Philippines-East ASEAN Growth Area (BIMP-EAGA), Australia-Indonesia Development Area (AIDA), Asia Timur, dan Pasifik).

- Berdekatan dengan adanya rencana pengembangan International Hub Port (IHP).

Potensi geostrategis yang dimiliki Bitung, yaitu telah terintegrasi dengan konsep pengembangan: Kawasan Pengembangan Ekonomi Terpadu (KAPET) Manado-Bitung, jaringan jalan tol Manado-Bitung, dan pelabuhan hub international Bitung (Dewan Nasional KEK, 2015). Infrastruktur jalan tol Manado-Bitung dibangun untuk: (1) meningkatkan pengembangan wilayah sepanjang jalan tol; (2) menunjang KAPET Manado-Bitung; (3) mendukung pembangunan IHP/Global Hub Bitung dan Bandara Internasional Sam Ratulangi.

Pembangunan infrastruktur IHP diarahkan sebagai gerbang utama perdagangan Bitung (mengurangi ketergantungan kepada pelabuhan yang ada di Jawa). IHP diharapkan menjadi pintu masuk dan keluar barang (wilayah domestik maupun luar negeri), serta pelabuhan komplementer untuk bagian timur (pelabuhan bebas alternatif). Peningkatan perdagangan melalui pelabuhan nantinya memberikan imbas terhadap kegiatan produksi, serta pelayanan yang terkait. Hal ini mengakibatkan produksi semakin meningkat dan terjadi secara terus menerus atau disebut multiplier effect (dampak penggandaan yang berlangsung semakin bertambah besar) (wawancara dengan pelaku usaha Bitung, 29/08/2014). Keterpaduan pembangunan prasarana (darat, laut, dan udara) dapat mendukung penyelenggaraan transportasi antar-moda (multi moda), dalam penyediaan pelayanan angkutan yang berkesinambungan (Adisasmita, 2013:43).

Keuntungan daerah yang ditetapkan menjadi KEK: (1) anggaran pembangunan infrastruktur dibiayai melalui APBN dan APBD; (2) kelonggaran aturan kepabeanan dan kepelabuhan; (3) kelonggaran aliran barang, uang, dan orang (Lilis Mulyani dalam Hidayat dan Hidayat, 2010:69). Kebijakan pembentukan KEK Bitung ketentuannya sudah diatur di dalam Pasal 9, Ayat (4), UU No. 32/2004, dengan perubahan terakhir melalui UU No. 12/ 2008.

Pasal 9, Ayat (4), UU No. 32/2004 (perubahan terakhir melalui UU No. 12/2008):

(4) Untuk membentuk kawasan khusus sebagaimana dimaksud pada ayat (2) dan ayat (3), Pemerintah mengikutsertakan daerah yang bersangkutan.

Pembangunan infrastruktur di Bitung, tidak terlepas dengan sistem pembangunan yang telah dirancang pada saat pengembangan KAPET. Operasionalisasi KAPET merupakan bagian 
perencanaan Pemkot dan Pemprov, yang secara tidak langsung menjadi titik awal pembentukan KEK Bitung (wawancara dengan pejabat BAPPEDA Provinsi Sulawesi Utara, 30/08/2014). Penetapan KEK Bitung merupakan kebijakan pemerintah yang tepat, karena wilayahnya memiliki keunggulan sumber daya alam dan sudah didukung infrastruktur yang baik, serta memiliki program pengembangan pembangunan ekonomi yang terencana (wawancara dengan pelaku usaha Bitung, 29/08/2014). Menurut Purba (2006:126), KEK tidak akan pernah dibangun di daerah yang masih terbatas pembangunan sarana dan prasarananya, serta tidak dapat diharapkan untuk mendorong pembangunan daerah yang masih belum maju.

\section{Perkembangan Investasi Bitung}

Pengembangan kebijakan publik terhadap investasi melalui KEK sudah dinyatakan sejak berlakunya UU Nomor 32 Tahun 2004, tentang Pemerintahan Daerah (UU No. 32/2004), dengan perubahan terakhir melalui UU Nomor 12 Tahun 2008, tentang Perubahan Kedua atas Undang-Undang Nomor 32 Tahun 2004 tentang Pemerintahan Daerah (UU No. 12/2008). Investasi merupakan suatu pengeluaran sejumlah dana dari investor guna membiayai kegiatan produksi untuk mendapatkan profit di masa yang akan datang (Pujoalwanto, 2014:163). Kebutuhan investasi KEK Bitung menuntut kolaborasi otoritas pusat dan daerah untuk memenuhi tugas, serta tanggung jawab terhadap tata laksananya. Perkembangan perusahaan Penanaman Modal Asing (PMA) dan Penanaman Modal Dalam Negeri (PMDN) (2010 sampai dengan Triwulan I-2014) yang berinvestasi di Bitung, dapat dilihat pada Gambar 2.

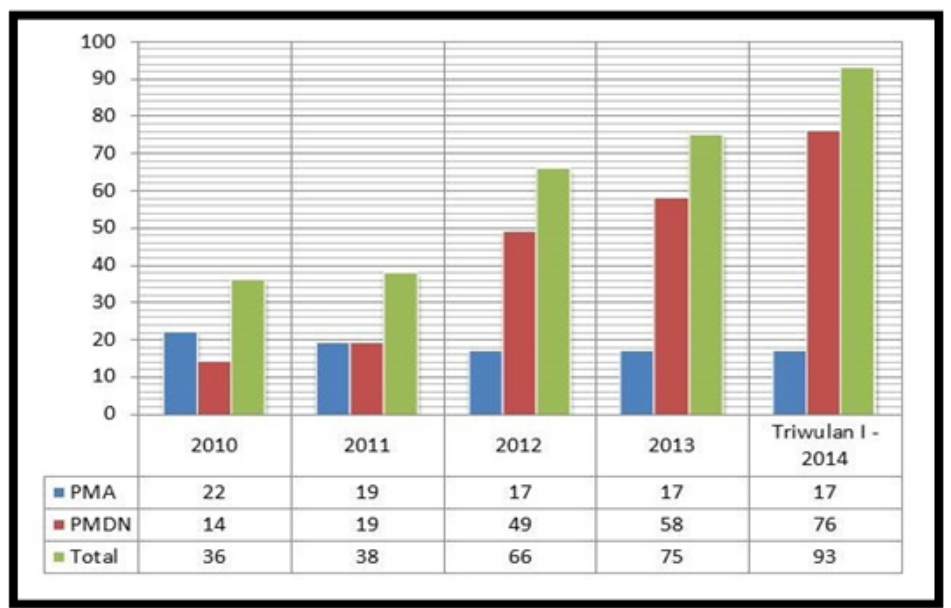

Sumber: BPPTPMD Kota Bitung (2013)

Gambar 2.

Jumlah Perusahaan PMA dan PMDN di Bitung

Berdasarkan Gambar 2, diketahui bahwa sejak 5 tahun terakhir jumlah perusahaan PMA yang berinvestasi di Bitung menurun. Penurunan ini disebabkan adanya perusahaan yang merugi (salah satu pemicunya adalah daya dukung listrik tidak mencukupi) dan tidak dapat bersaing dengan perusahaan sejenis lainnya (wawancara dengan masyarakat dan pelaku usaha Bitung, 29/08/2014). Pada tahun 2014, terdapat 17 perusahaan PMA (1 sektor primer, 12 sektor sekunder, dan 3 sektor tersier) yang berinvestasi di Bitung.

Perusahaan PMDN yang berinvestasi pada kawasan Bitung semakin bertambah jumlahnya sejak tahun 2010. Bertambahnya investasi PMDN dikarenakan nilai keuntungan 
sumber daya alam Bitung sangat menjanjikan (wawancara dengan pelaku usaha Bitung, 29/ 08/2014). Pada tahun 2013, perusahaan PMDN yang beroperasi pada sektor primer sebanyak 1 perusahaan, sekunder: 9 perusahaan, dan tersier: 18 perusahaan. Nilai investasi PMA dan PMDN di Bitung (2010-Triwulan I-2014), dapat dilihat pada Gambar 3.

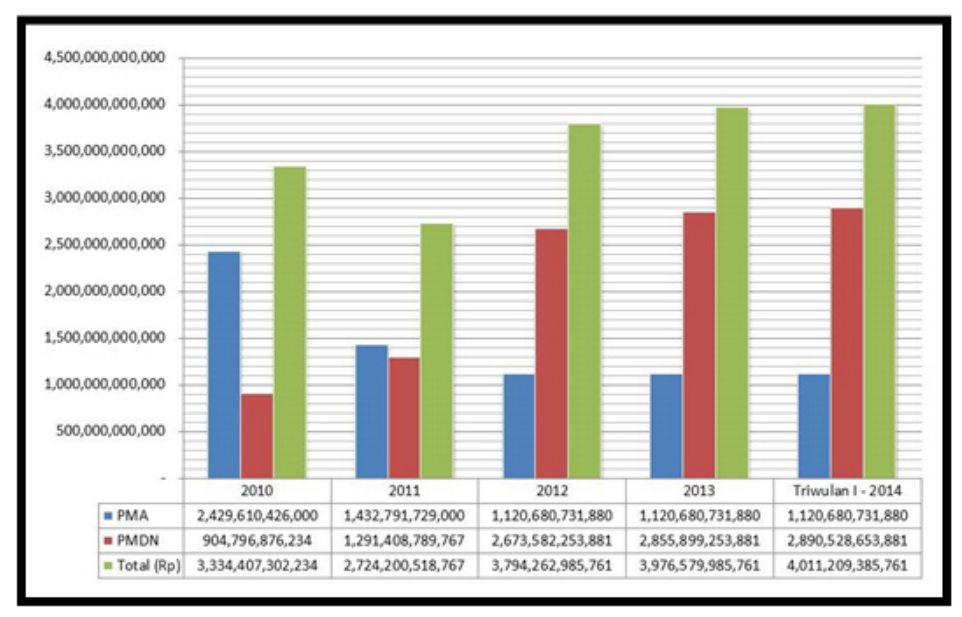

Sumber: BPPTPMD Kota Bitung (2013)

Gambar 3.

Investasi PMA dan PMDN di Bitung

Gambar 3, menunjukkan bahwa nilai investasi untuk PMA mengalami penurunan (iklim investasi di Bitung dirasakan belum menguntungkan bagi investor), sedangkan investasi PMDN sejak 5 tahun terakhir meningkat. Kenaikan investasi PMDN ini dikarenakan situasi usaha yang semakin kondusif. Berdasarkan hasil wawancara dengan pejabat BPPTPMD Bitung (28/08/2014), diketahui bahwa investor pada sektor PMDN merasakan bahwa Bitung memiliki kapasitas dijadikan tempat usaha (meskipun sudah ada perusahaan yang lebih dahulu berinvestasi untuk sektor usaha yang sama). Pelaku usaha Bitung (29/08/2014), menyatakan bahwa Pemda Kota Bitung telah memberikan kemudahan perizinan dalam berinvestasi.

Alokasi investasi PMDN di Bitung ditanamkan pada sektor: (1) peternakan; (2) industri makanan dan minuman; (3) kimia dan farmasi; (4) alat transportasi; (5) industri lainnya; (6) listrik, gas, dan air bersih; (7) pembangunan jasa konstruksi; (8) perdagangan; (9) hotel dan restaurant; (10) gudang; (11) telekomunikasi. Distribusi investasi perusahaan PMDN tersebar pada wilayah kecamatan: Aertembaga, Girian, Lembeh Selatan, Madidir, Mesa, dan Matuari. Sektor usaha yang diminati investor PMA meliputi: perikanan; makanan dan minuman; kimia dan farmasi; alat transportasi kegiatan industri; industri lainnya; serta hotel dan restaurant. Negara asal perusahaan PMA yang beroperasi di Bitung: Philipina, Taiwan, Jepang, Belanda, Korea Selatan, Singapura, dan USA.

Promosi yang dilakukan untuk menarik investor dengan adanya kebijakan KEK Bitung meskipun belum maksimal, tetapi sudah memberikan hasil (wawancara dengan masyarakat dan pelaku usaha Bitung, 29/08/2014). Perkembangan investasi pembangunan daerah Bitung, merupakan potret kesiapan wilayah tersebut menjadi KEK. Wilayah Bitung terletak pada Alur Laut Kepulauan Indonesia (ALKI) 3 (Laut Maluku dan Samudera Pasifik), yang dilayari oleh kapal besar dari berbagai negara. Bitung juga memiliki akses langsung menuju luar negeri, tanpa harus melalui pelabuhan di Jakarta ataupun Surabaya untuk sampai ke negara 
tujuan (waktu lebih efisien dan mengurangi biaya logistik untuk ekspor). Jalur pelayaran strategis inilah yang memberikan kontribusi terhadap percepatan dan perluasan pembangunan ekonomi Bitung dan nasional, khususnya sektor perikanan. Menurut pelaku usaha Bitung (29/08/2014), salah satu upaya yang telah dilakukan oleh otoritas daerah adalah dengan mengeluarkan kebijakan tidak memungut retribusi kepada seluruh perusahaan perikanan. Tujuan dikeluarkannya kebijakan ini adalah merangsang investor lokal dan asing berinvestasi ke Bitung.

Suatu negara tidak hanya dituntut untuk menarik investor, karena yang terpenting dari semua itu bagaimana memberikan kenyaman investasi yang masuk bisa bertahan. Aspek penting lainnya yang terkait dengan masuknya investasi pada KEK Bitung, yaitu keterlibatan masyarakat sebagai pekerja (wawancara dengan pejabat BAPPEDA Bitung, 27/08/2014). Aktivitas investasi pada sektor perikanan Bitung merupakan penyumbang ekonomi utama dan penyerap tenaga kerja terbesar (tidak hanya penduduk lokal, melainkan juga daerah sekitarnya). Peran penting kebijakan daerah melindungi pekerja, adalah menjaga agar kepentingan (hak dan kewajiban) mereka sesuai dengan porsinya (tidak dilanggar). Penentu kebijakan daerah harus menghasilkan peraturan yang mampu mengawal keterlibatan masyarakat lokal, sebagai penggerak investasi KEK Bitung. Perlindungan dan eskalasi kompetensi tenaga kerja sangat dibutuhkan, dalam rangka peningkatan produktivitas proses produksi (wawancara dengan masyarakat dan pelaku usaha Bitung, 29/08/2014).

Investasi memegang peran vital bagi pertumbuhan ekonomi Bitung. Terciptanya akumulasi modal dapat meningkatkan produktivitas seiring meningkatnya investasi (wawancara dengan pejabat BKPM Provinsi Sulawesi Utara, 30/08/2014). Usaha menarik investor (dalam maupun asing) untuk masuk ke KEK Bitung harus terus diupayakan, terutama memperbaiki iklim investasi. Pelaku usaha Bitung (29/08/2014), menyatakan bahwa perbaikan yang harus dilakukan: (1) menyederhanakan prosedur perizinan; (2) mengurangi tumpang tindihnya kebijakan pusat dan daerah, serta antar sektor; (3) meningkatkan dan mempercepat penyediaan infrastruktur; (4) meningkatkan fungsi intermediasi perbankan dalam menyalurkan kredit kepada sektor usaha; (5) menyehatkan iklim ketenagakerjaan.

\section{Kebijakan Lokal Kawasan Ekonomi Khusus Bitung}

Hukum dan politik menjadi penting sejak hukum merupakan instrumen kebijakan. Hukum adalah perwujudan kebijakan publik ditinjau dari sisi produk, proses, dan muatan. Produk hukum yang digunakan mengontrol kegiatan investasi di Bitung, mempunyai misi mengakomodir kepentingan ekonomi masyarakat (wawancara dengan pejabat Pemprov Sulawesi Utara, 30/08/2014). Kebijakan secara garis besar memiliki tujuan dan sasaran, namun cara yang digunakan biasanya tidak dijelaskan secara spesifik (Enceng dan Madya, 2014:4). Hal ini sesuai dengan amanat PP No. 32/2014, yang menekankan bahwa pemerintah memiliki program meningkatkan kegiatan perekonomian (investasi) Bitung. PP No. 32/2014, bersifat strategis bagi pembangunan nasional dan kesejahteraan masyarakat.

Konsepsi investasi pada ranah perdagangan bebas, mengharuskan Pemkot Bitung membuat kebijakan yang mengatur terjadinya iklim usaha yang sehat (wawancara dengan pelaku usaha Bitung, 29/08/2014). Terciptanya iklim usaha yang kondusif, menyebabkan prekonomian menjadi berkembang dan kegiatan investasi meningkat. Upaya merealisasikannya membutuhkan pembentukan suatu aturan main/kebijakan di bidang perundangan (Tri F. Mounty dalam Halim dan Damayanti, 2007:119). Salah satu fungsi hukum yaitu menyediakan 
jalur bagi pembangunan politik, ekonomi, dan sosial budaya (Mochtar Kusumaatmadja dalam Sulistiyono dan Rustamaji, 2009:6).

Pembuatan peraturan lokal yang tidak berpihak pada pertumbuhan ekonomi daerah dan peningkatan kesejahteraan masyarakat, dianggap telah menyebabkan terjadinya pelambatan bahkan kemerosotan daerah (BAPPENAS, 2008:ii). Pembentukan peraturan lokal mempunyai fungsi sebagai acuan dan payung hukum, agar tidak terjadi penyalahgunaan wewenang selama pelaksanaan KEK Bitung. Identifikasi peraturan lokal pendukung KEK Bitung, dapat dilihat pada Tabel 2.

Tabel 2.

Regulasi Daerah Pendukung KEK Bitung

\begin{tabular}{|c|c|c|c|}
\hline No. & Regulasi & Dasar Pembentukan & Relevansi \\
\hline 1. & $\begin{array}{l}\text { Peraturan Daerah Kota Bitung } \\
\text { Nomor } 11 \text { Tahun 2013, tentang } \\
\text { Rencana Tata Ruang Wilayah } \\
\text { Kota Bitung Tahun 2013- } \\
\text { 2033/Perda Kota Bitung No. } \\
\text { 11/2013 }\end{array}$ & $\begin{array}{l}\text { Peraturan ini dibentuk untuk } \\
\text { mengarahkan tujuan } \\
\text { pembangunan wilayah Kota } \\
\text { Bitung (meliputi pemanfaatan } \\
\text { ruang dan sumber daya alam } \\
\text { yang terkandung di dalamnya) }\end{array}$ & $\begin{array}{l}\text { Perda Kota Bitung No. 11/2013, } \\
\text { merupakan dasar untuk } \\
\text { mengembangkan pemanfaatan } \\
\text { wilayah dan potensi sumber daya } \\
\text { Bitung secara terpadu }\end{array}$ \\
\hline 2. & $\begin{array}{l}\text { Peraturan Daerah Kota Bitung } \\
\text { Nomor: } 7 \text { Tahun 2011, tentang } \\
\text { Rencana Pembangunan Jangka } \\
\text { Menengah Daerah (RPJMD) } \\
\text { Tahun 2011-2016 Kota } \\
\text { Bitung/Perda Kota Bitung No. } \\
\text { 7/2011 }\end{array}$ & $\begin{array}{l}\text { Peraturan ini dibentuk untuk } \\
\text { memberikan petunjuk kebijakan } \\
\text { tindakan pemerintah dan } \\
\text { masyarakat, yang disusun melalui } \\
\text { pendekatan perencanaan yang } \\
\text { terstruktur }\end{array}$ & $\begin{array}{l}\text { Perda Kota Bitung No. } 7 / 2011 \text {, } \\
\text { menjadi landasan yuridis bagi } \\
\text { dinas/badan/kantor di lingkungan } \\
\text { Pemkot Bitung, masyarakat } \\
\text { (dunia usaha), dan lembaga } \\
\text { swadaya masyarakat, dalam } \\
\text { melaksanakan visi, misi, serta } \\
\text { kebijakan program pembangunan } \\
\text { daerah kota Bitung }\end{array}$ \\
\hline 3. & $\begin{array}{l}\text { Peraturan Daerah Kota Bitung } \\
\text { Nomor: } 6 \text { Tahun 2009, tentang } \\
\text { Tata Cara Penanaman Modal } \\
\text { Dalam Negeri dan Penanaman } \\
\text { Modal Asing di Kota } \\
\text { Bitung/Perda Kota Bitung No. } \\
\text { 6/2009 }\end{array}$ & $\begin{array}{l}\text { Peraturan ini dibentuk untuk } \\
\text { mempercepat pembangunan Kota } \\
\text { Bitung dan menjamin } \\
\text { kelangsungan penanaman modal }\end{array}$ & $\begin{array}{l}\text { Perda Kota Bitung No. } 6 / 2009 \text {, } \\
\text { adalah pedoman untuk } \\
\text { mengembangkan iklim investasi } \\
\text { yang tertib di kawasan Bitung }\end{array}$ \\
\hline 4. & $\begin{array}{l}\text { Peraturan Daerah Kota Bitung } \\
\text { Nomor: } 7 \text { Tahun 2009, tentang } \\
\text { Penyelenggaraan Pelayanan } \\
\text { Perijinan Terpadu di Kota } \\
\text { Bitung/Perda Kota Bitung No. } \\
\text { 7/2009 }\end{array}$ & $\begin{array}{l}\text { Peraturan ini dibentuk dalam } \\
\text { rangka menyelenggarakan iklim } \\
\text { investasi yang kompetitif di Kota } \\
\text { Bitung }\end{array}$ & $\begin{array}{l}\text { Perda Kota Bitung No. } 7 / 2009 \text {, } \\
\text { merupakan panduan untuk } \\
\text { memudahkan pelaku usaha yang } \\
\text { ingin menanamkan modalnya } \\
\text { pada kawasan Bitung }\end{array}$ \\
\hline 5. & $\begin{array}{l}\text { Peraturan Walikota Bitung } \\
\text { Nomor: } 19 \text { Tahun 2013, tentang } \\
\text { Standar Operasional Prosedur } \\
\text { Penyelenggaraan Pelayanan } \\
\text { Perizinan di Badan Pelayanan } \\
\text { Perizinan Terpadu dan } \\
\text { Penanaman Modal Daerah Kota } \\
\text { Bitung/Perwa Bitung No. } \\
\text { 19/2013 }\end{array}$ & $\begin{array}{l}\text { Peraturan ini dibentuk untuk } \\
\text { lebih mengoptimalkan pelayanan } \\
\text { kepada masyarakat, sebagai } \\
\text { upaya menumbuhkan kepuasan } \\
\text { masyarakat (terutama pelaku } \\
\text { usaha) }\end{array}$ & $\begin{array}{l}\text { Perwa Bitung No. 19/2013, } \\
\text { merupakan ketentuan teknis } \\
\text { sebagai upaya memberikan } \\
\text { kenyamanan kepada pelaku usaha } \\
\text { yang berinvestasi di Bitung }\end{array}$ \\
\hline 6. & $\begin{array}{l}\text { Peraturan Walikota Bitung } \\
\text { Nomor: } 45 \text { Tahun 2008, tentang } \\
\text { Rincian Tugas, Fungsi dan Tata } \\
\text { Kerja Badan Pelayanan Perijinan } \\
\text { Terpadu dan Penanaman Modal } \\
\text { Daerah Kota Bitung/Perwa } \\
\text { Bitung No. 45/2008) }\end{array}$ & $\begin{array}{l}\text { Peraturan ini dibentuk sebagai } \\
\text { panduan mengetahui susunan } \\
\text { organisasi, kedudukan tugas dan } \\
\text { fungsi, serta tata kerja } \\
\text { BPPTPMD Kota Bitung (2013) } \\
\text { Kota Bitung }\end{array}$ & $\begin{array}{l}\text { Perwa Bitung No. } 45 / 2008 \text {, } \\
\text { merupakan koridor kewenangan } \\
\text { bagi BPPTPMD Kota Bitung } \\
\text { dalam menjalankan } \\
\text { kewajibannya }\end{array}$ \\
\hline
\end{tabular}


Berdasarkan Tabel 2, diketahui bahwa kesiapan Pemkot Bitung menjalankan program KEK telah dilaksanakan dengan menerbitkan peraturan pendukungnya. Penerbitan peraturan lokal tersebut adalah hasil kebijakan yang dibentuk sebelum Bitung disahkan menjadi KEK pada tahun 2014 (wawancara dengan pejabat Pemkot Bitung, 27/08/2014).

Kemungkinan dampak negatif program KEK Bitung yang muncul, harus dapat dikendalikan dengan mengeluarkan kebijakan/regulasi yang benar dan dibarengi dengan pendampingan pelaksanaan yang konsisten (wawancara dengan masyarakat dan pelaku usaha Bitung, 29/08/2014). Keuntungan yang diterima jika mampu mengantisipasi dampak negatif: (1) menciptakan daya tarik secara langsung bagi penanam modal untuk berinvestasi; (2) menyerap tenaga kerja/mengurangi pengangguran; (3) meningkatkan PDRB dan pendapatan masyarakat; (4) menciptakan akses ke pasar dunia; (5) mendorong terjadinya alih teknologi yang dapat meningkatkan kualitas sumber daya manusia; (6) meningkatkan penjualan dalam negeri (pemanfaatan produk lokal); (7) menambah devisa negara.

Implementasi kebijakan merupakan aktivitas yang terlihat setelah dikeluarkannya pengarahan yang sah dari suatu kebijakan, yang meliputi upaya mengelola input untuk menghasilkan output atau outcomes bagi masyarakat (Akib, 2010:1). Keterpaduan pembangunan Bitung harus ditopang menggunakan produk hukum yang komprehensif, disertai dengan penerapan yang benar dan tegas. Implementasi regulasi lokal pendukung KEK Bitung, sangat bergantung kepada pemahaman personel struktural di lapangan. Kejelasan pengelolaan regulasi menjadi faktor sentral mempercepat pengambilan keputusan, menghindari transaksi bisnis berbiaya tinggi, mempertahankan investasi, menjaga ketertiban pelaksanaan, memberikan kenyamanan kepada investor, serta melindungi masyarakat lokal (wawancara dengan pelaku usaha Bitung, 29/08/2014). Terciptanya bangunan hukum yang baik, dapat membentuk harmonisasi pengembangan KEK Bitung yang tertib dan terarah.

\section{Kesiapan Bitung sebagai Kawasan Ekonomi Khusus}

Pengembangan KEK Bitung bagi Pemprov Sulawesi Utara bukan sebagai wacana baru, melainkan melengkapi program KAPET yang sudah ada terlebih dahulu. Menurut Prabowo dalam Hidayat dan Hidayat (2010:23):

"KEK hendaknya merupakan instrumen kebijakan industri dan kebijakan pembangunan wilayah yang secara sengaja dan terstruktur memfasilitasi berbagai skema industrial upgrading, training and $R \& D$, backward linkage, enterprise development (termasuk UKM), dan lain-lain. Tanpa keterkaitan yang jelas dan terarah, maka skema KEK akan tetap menjadi enclave, terjebak dalam produksi padat karya dan teknologi rendah, tergantung kepada pihak luar yang pada akhirnya tidak memberikan manfaat optimal pada ekonomi domestik".

Pembangunan wilayah melalui program KAPET, membuat Bitung cukup dikenal untuk kawasan Indonesia bagian timur. Program KAPET secara langsung telah menambah daya tarik investasi di Provinsi Sulawesi Utara. Arah pembangunan KEK Bitung dan KAPET memiliki tujuan yang hampir sama, tetapi dengan bentuk kemasan yang berbeda. Orientasi besar kedua program ini pada prinsipnya, memberikan kemudahan kepada investor (PMDN dan PMA) yang terhambat masalah regulasi dan ekonomi berbiaya tinggi (wawancara dengan pejabat BAPPEDA Bitung, 27/08/2014).

Regulasi nasional maupun lokal yang lahir sebagai pijakan KEK, adalah organ (alat kelengkapan) Pemprov Sulawesi Utara untuk mengembangkan potensi sumber daya wilayah 
otonominya. Profil potensi ekonomi Bitung dipengaruhi oleh faktor lingkungan internal dan eksternal (nasional). Menurut pelaku usaha Bitung (29/08/2014), pengelolaan wilayah yang baik, bisa menjadikan faktor lingkungan sebagai kekuatan menarik investasi dalam mensejahterakan masyarakat. Rekam jejak penetapan dan penerapan program KEK Bitung, dapat dilihat pada Gambar 4.

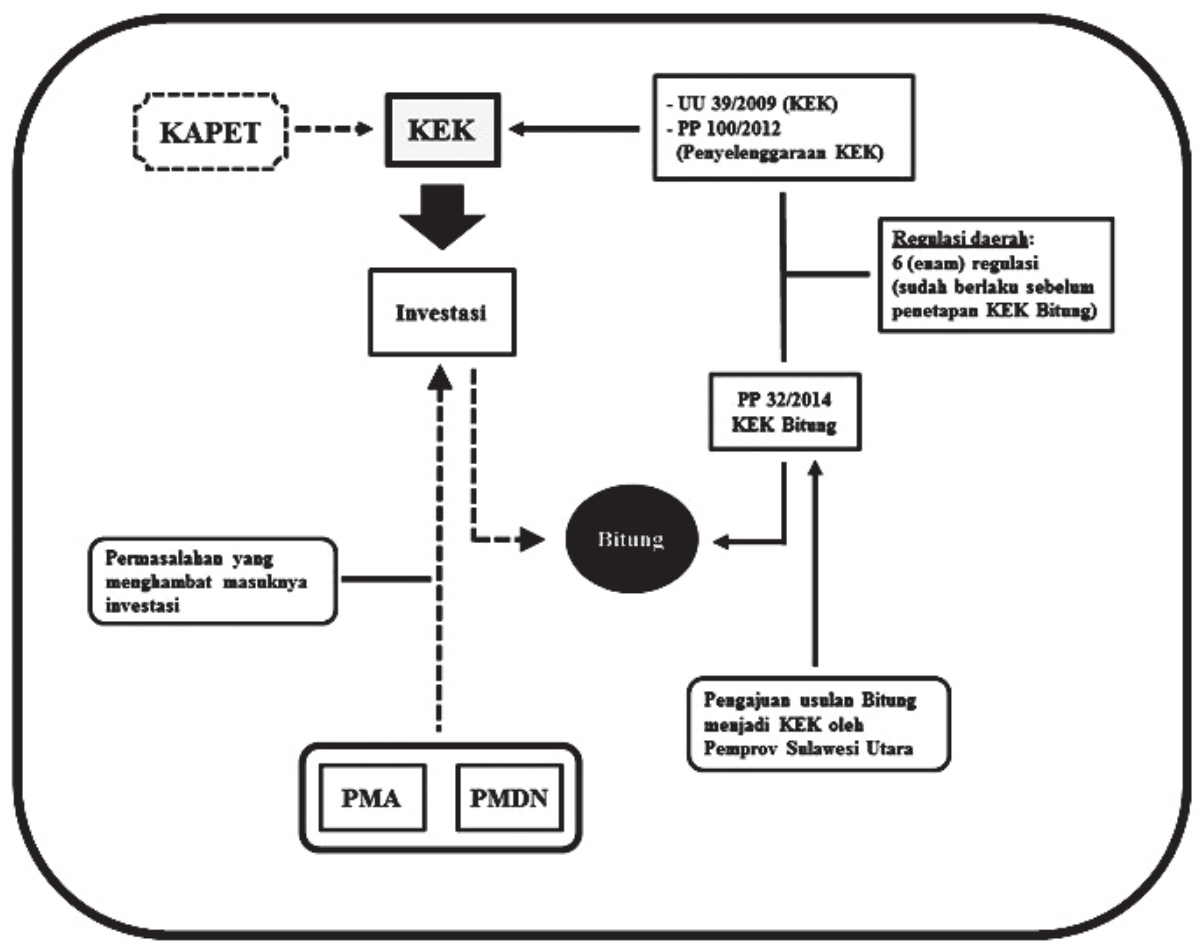

Gambar 4.

KEK Bitung dan Implementasinya

Berdasarkan Gambar 4, diketahui bahwa aktualisasi pembangunan infrastruktur KEK Bitung belum sepenuhnya berjalan sesuai dengan rencana.

Kendala yang paling dirasakan menjadi hambatan adalah masalah pembebasan lahan. Harga tanah yang sudah siap digunakan sebagai tempat pembangunan proyek mengalami lonjakan kenaikan. Kenaikan nilai jual tanah sebenarnya memang seharusnya terjadi. Rencana pembangunan infrastruktur KEK Bitung, secara tidak langsung memberikan kepastian adanya kegiatan ekonomi yang nantinya meningkat. Kondisi tersebut dimanfaatkan oleh spekulan tanah untuk menaikkan harganya, karena melihat keuntungan besar. Situasi ini menimbulkan kerugian, sehingga menyebabkan penyelesaian pembangunan yang ditargetkan menjadi tidak sesuai dengan rencana (wawancara dengan masyarakat dan pelaku usaha Bitung, 29/08/2014).

Pemberdayaan basis potensi kawasan membutuhkan adanya sinergitas pemerintah pusat dan daerah, sebagai pemicu pembangunan pada wilayah pertumbuhan ekonomi baru. (Alkadri, 2011:8). Peran pemangku kebijakan daerah untuk mengatasi permasalahan lahan, membutuhkan sikap yang bijaksana dan tidak hanya sekedar menggunakan pendekatan bisnis. Hal tersebut disebabkan, masih adanya kepemilikan tanah adat yang sudah dihuni oleh masyarakat secara turun temurun (wawancara dengan masyarakat Bitung, 29/08/2014). Pemerintah pusat harus menggiatkan otoritas daerah melakukan pendekatan secara sosiologis kepada masyarakat, yang lahannya terkena dampak KEK. Sikap ini diperlukan sebagai kontrol, 
bahwa hasil akhir arah pelaksanaan program KEK Bitung harus dapat bermanfaat juga bagi masyarakat dan bukan hanya untuk segolongan orang saja. Ketegasan pelaksana kebijakan daerah menyelesaikan masalah pembebasan lahan, bisa memberikan keuntungan tersendiri (masyarakat yang lahannya terkena proyek mendapatkan imbalan setimpal dan pembangunan dapat segera diselesaikan).

Keinginan mengakselerasi perekonomian melalui investasi masih menghadapi tantangan lainnya, terutama daya pasokan listrik (wawancara dengan pejabat Pemkot dan PPS Bitung, 27/08/2014). Listrik merupakan kebutuhan utama menjalankan operasional usaha agar tetap terus lancar. Kekurangan pasokan energi listrik menyebabkan adanya perusahaan yang mengalami kebangkrutan. Calon pelaku usaha yang ingin menanamkan modalnya di Bitung akan berpikir ulang, ketika mengetahui kondisi listrik kurang memadai energinya. Kurangnya energi listrik mempengaruhi pencapaian target dan berdampak terhadap pendapatan yang diterima, serta mengancam keberlangsungan usaha investor. Pelaku usaha Bitung (29/08/ 2014), berpendapat bahwa upaya mengatasi kekurangan energi listrik sebenarnya dapat disikapi dengan menggunakan genset, akan tetapi memberikan konsekuensi meningkatnya biaya produksi (berlipat ganda). Situasi ini harus segera diselesaikan, agar daya saing KEK Bitung diperhitungkan oleh investor.

Kekuasaan dan kewenangan memiliki pengaruh efektif dalam setiap tindakan, serta keputusan kebijakan yang diambil untuk mencapai tujuan. Kebijakan pengukuhan KEK Bitung seharusnya tidak hanya disosialisasikan kepada institusi daerah saja, tetapi juga kepada masyarakat. Proses sosialisasi KEK Bitung, pada kenyataannya belum sampai ke masyarakat (hanya di tingkat instansi daerah terkait saja) (wawancara dengan masyarakat Bitung, 29/08/ 2014). Kebijakan sebesar ini seharusnya perlu disosialisasikan kepada masyarakat (pihak pengguna maupun penerima manfaat). Masyarakat akan menjadi pihak yang paling dirugikan, jika proses pembangunan yang terkait dengan KEK Bitung mengalami kegagalan.

Proses sosialisasi hukum sangat diperlukan, agar masyarakat berperilaku sebagaimana yang diharapkan oleh hukum (Abdurrahman, 2009:89). Pelaksanaan sosialisasi yang benar membutuhkan waktu yang tidak sebentar dan harus terorganisasi secara rapi. Sosialisasi kepada masyarakat sangat penting untuk memberikan pemahaman mengenai adanya kebijakan baru. Hal tersebut bertujuan agar maksud dikeluarkannya PP No. 32/2014, bisa diaplikasikan dengan baik (tidak menghambat proses pembangunan). Apabila kebijakan mempunyai tujuan tidak jelas atau tidak diketahui oleh kelompok sasaran, maka besar kemungkinan penerapannya menimbulkan resistensi.

Kebijakan pengembangan KEK Bitung diarahkan sebagai pelengkap komponen peningkatan pertumbuhan ekonomi daerah maupun nasional. Pertumbuhan ekonomi bukan satu-satunya sasaran pembangunan, melainkan hanya satu dari sekian banyak aspek pembangunan (Lingga dan Pratomo, 2013:14). Pertumbuhan ekonomi bukan satu-satunya sasaran pembangunan, melainkan hanya satu dari sekian banyak aspek pembangunan. Menurut RKPD Kota Bitung (2012:34):

"Pertumbuhan ekonomi suatu daerah belum tentu menunjukkan peningkatan kemakmuran masyarakatnya. Indikator kesejahteraan masyarakat juga ditentukan oleh pemerataan akan hasil-hasil pembangunan. Pertumbuhan ekonomi yang tinggi dengan diikuti oleh pertumbuhan penduduk yang tinggi pula menyebabkan tidak meningkatnya pendapatan per kapita. Demikian juga dengan pemerataan kesejahteraan, tingginya laju pendapatan tidak selalu diikuti oleh meratanya pendapatan yang diterima masyarakat. 
Menurut masyarakat Bitung (29/08/2014), mereka sebagai subyek dan sekaligus obyek dalam pembangunan harus tetap mendapat prioritas utama. Hal ini mengingat, bahwa sasaran utama pembangunan yaitu peningkatan taraf hidup masyarakat.

Kebijakan KEK telah memberikan implikasi yang positif bagi pembangunan wilayah Bitung. Penetapan Bitung sebagai kawasan KEK secara operasional sudah dirasakan manfaatnya oleh masyarakat nelayan dan pelaku usah perikanan. Manfaat ini secara keseluruhan mendukung terhadap kesiapan penumbuhan usaha industri besar skala nasional (wawancara dengan masyarakat dan pelaku usaha Bitung, 29/08/2014). Kesiapan Bitung sebagai kawasan pengembangan perekonomian nasional pada kerangka KEK, karena memiliki: (1) posisi geografis yang strategis; (2) manfaat lebih setiap potensi sumber dayanya (khususnya perikanan); (3) perkembangan investasi yang baik; (4) payung hukum lokal yang mengawal kelancaran investasi; (5) dukungan Pemda terhadap alokasi anggaran untuk pengembangan kawasan KEK.

\section{PENUTUP}

\section{Kesimpulan}

Lahirnya KEK merupakan kebijakan pemerintah dalam mengelola potensi lahan penambah devisa negara. Aplikasi kebijakan penetapan KEK telah memberikan pengaruh positif terhadap pembangunan infrastruktur Kota Bitung. Investasi yang masuk dengan adanya kebijakan KEK, merupakan sinergitas pemerintah pusat dan daerah dalam menata atmosfer usaha yang produktif bagi penanam modal. Representasi investasi yang terjadi atas kepentingan KEK Bitung, salah satunya ditunjang dengan adanya regulasi daerah, sebagai aksi reaktif untuk menarik pemodal. Regulasi lokal yang dibentuk telah menciptakan aktivitas yang sehat bagi iklim usaha. Hal tersebut menjadi kontribusi penting dalam meningkatkan kegiatan ekonomi lokal, penyerapan tenaga kerja, serta tumbuhnya industri pada kawasan KEK Bitung. Secara umum implementasi program KEK di wilayah Bitung sudah baik, meskipun masih ada kendala yang harus segera ditindaklanjuti. Pengembangan pembangunan ekonomi Bitung yang dilaksanakan otoritas daerah, sudah sesuai dan mendukung tujuan penetapan kebijakan KEK oleh pemerintah.

\section{Rekomendasi Kebijakan}

Pembangunan infrastruktur Kota Bitung sebagai wilayah KEK, dalam pelaksanaannya tidak terlepas adanya hambatan. Konsekuensi menyikapi hambatan tersebut, aplikasinya membutuhkan tata kelola operasional yang baik dan terencana. Kemitraan antara pemerintah pusat, daerah, maupun swasta harus lebih diperkuat, serta dilakukan secara terkonsolidasi dan tersinkronisasi untuk menyelenggarakan sosialisasi KEK Bitung kepada masyarakat. Langkah strategis yang dapat dilakukan oleh otoritas daerah mengatasi pembebasan lahan untuk kepentingan KEK Bitung, perlu menggunakan pendekatan kepada masyarakat dan bukan semata hanya kepentingan hitungan angka. Pembangunan infrastruktur untuk menambah daya pasok listrik harus menjadi prioritas utama, agar investasi yang masuk (terutama sektor industri perikanan) semakin besar. Pengelolaan pembangunan KEK yang terprogram, dapat mengoptimalkan dan mempercepat tumbuhnya perekonomian Bitung sebagai sarana mewujudkan kesejahteraan masyarakat. 


\section{DAFTAR PUSTAKA}

Abdurrahman, M. (2009). Sosiologi dan Metode Penelitian Hukum. Malang: UMM Press

Adisasmita, R. (2013). Pembangunan Ekonomi Maritim. Yogyakarta: Graha Ilmu

Akib, H. (2010). Implementasi Kebijakan; Apa, Mengapa, dan Bagaimana. Jurnal Ilmu Administrasi Publik. Makassar: Universitas Negeri Makassar, Volume 1, Nomor 1, Februari 2010. (1-11)

Alkadri. (2011). Kebijakan Pengembangan Kawasan Ekonomu Khusus (KEK) di Provinsi Banten. Jurnal Sains dan Teknologi Indonesia. Jakarta: Badan Pengkajian dan Penerapan Teknologi, Volume 13, Nomor 1, April 2011. (7-13)

BAPPENAS. (2008). Arti Penting Analisis Dampak Peraturan Perundang-Undangan "Regulatory Impact Assessment”. Jakarta: Kementerian Negara Perencanaan Pembangunan Nasional/Badan Perencanaan Pembangunan Nasional

BPPTPMD Kota Bitung. (2013). Perusahaan Penanaman Modal Dalam Negeri (PMDN) dan Penanaman Modal Asing (PMA) Berdasarkan Sektor (Tidak Dipublikasikan). Kota Bitung: Badan Pelayanan Perizinan Terpadu dan Penanaman Modal Daerah

Dewan Nasional KEK. (2015). Bitung. http://kek.ekon.go.id/kek-di-indonesia/bitung/(Tanggal diunduh: 23 Maret 2015)

Dye, T.R. (1995). Understanding Public Policy. New Jersey: Prentice Hall

Enceng dan F. Madya. (2014). Evaluasi Perumusan, Implementasi, dan Lingkungan Kebijakan. Jurnal Kebijakan Publik. Riau: Universitas Riau, Volume 5, Nomor 3, Maret 2014. (18)

Fauzi, S. (2013). Kesiapan dan Implementasi Industri Perikanan di KEK Bitung (Disampaikan pada acara FGD Pengembangan Pengolahan TTC Berbasis Pasar, 16 September 2013). Manado (Sulawesi Utara): Direktorat Jenderal Pengolahan dan Pemasaran Hasil Perikanan-Kementerian Kelautan dan Perikanan.

Halim, A. dan T.W. Damayanti. (2007). Seri Bunga Rampai Manajemen Keuangan Daerah (Pengelolaan Keuangan Daerah). Yogyakarta: Sekolah Tinggi Ilmu Manajemen YKPN

Hidayat, S. dan A.S. Hidayat. (2010). Quo Vadis Kawasan Ekonomi Khusus (KEK). Jakarta: Rajawali Pers-PT. RajaGrafindo Persada

Jhingan, M.L. (2013). Ekonomi Pembangunan dan Perencanaan. Jakarta: Rajawali Pers-PT. RajaGrafindo Persada

Kementerian Koordinator Bidang Perekonomian. (2011). Masterplan Percepatan Perluasan Pembangunan Ekonomi Indonesia 2011-2025. Kementerian Koordinator Bidang Perekonomian-Kementerian Perencanaan Pembangunan Nasional/Badan Perencanaan Pembangunan Nasional Ekonomi Indonesia. Jakarta: IndoPacific Edelman

Keputusan Menteri Koordinator Bidang Perekonomian Selaku Ketua Harian Komite Percepatan dan Perluasan Pembangunan Ekonomi Indonesia Nomor 60 tahun 2013, tentang Tim Kerja pada Komite Percepatan dan Perluasan Pembangunan Ekonomi Indonesia 2011-2025. Ditetapkan di Jakarta: 17 Mei 2013 
Lingga, D. dan W.A. Pratomo (2013). Persepsi Masyarakat terhadap Pengembangan Kawasan Ekonomi Khusus Sei Mangkei sebagai Klaster Industri. Jurnal Ekonomi dan Keuangan. Medan: Universitas Sumatera Utara, Volume 1, Nomor 2, Januari 2013. (13-20)

Madani, M. 2011. Dimensi Interaksi Aktor dalam Proses Perumusan Kebijakan Publik. Yogyakarta: Graha Ilmu

Nugroho, R. (2011). Public Policy (Dinamika Kebijakan-Analisis Kebijakan-Manajemen Kebijakan). Jakarta: PT. Elex Media Komputindo

Peraturan Daerah Kota Bitung Nomor 11 Tahun 2013, tentang Rencana Tata Ruang Wilayah Kota Bitung Tahun 2013-2033. Lembaran Daerah Kota Bitung Tahun 2013 Nomor 32. Tambahan Lembaran Daerah Kota Bitung Nomor 116

Peraturan Pemerintah Republik Indonesia Nomor 2 Tahun 2011, tentang Penyelenggaraan Kawasan Ekonomi Khusus. Lembaran Negara Republik Indonesia Tahun 2011 Nomor 3. Tambahan Lembaran Negara Republik Indonesia Nomor 5186, sebagaimana telah diubah dengan Peraturan Pemerintah Nomor 100 Tahun 2012, tentang Perubahan atas Peraturan Pemerintah Nomor 2 Tahun 2011 tentang Penyelenggaraan Kawasan Ekonomi Khusus. Lembaran Negara Republik Indonesia Tahun 2012 Nomor 263. Tambahan Lembaran Negara Republik Indonesia Nomor 5371

Peraturan Pemerintah Republik Indonesia Nomor 32 Tahun 2014, tentang Kawasan Ekonomi Khusus Bitung. Lembaran Negara Republik Indonesia Tahun 2014 Nomor 106. Tambahan Lembaran Negara Republik Indonesia Nomor 5537

Pujoalwanto, B. (2014). Perekonomian Indonesia (Tinjauan Historis, Teoritis, dan Empiris). Yogyakarta: Graha Ilmu

Purba, H. (2006). Kawasan Ekonomi Khusus (KEK) Fenomena Global: Suatu kajian Aspek Hukum. Jurnal Hukum Equality. Medan: Universitas Sumatera Utara, Volume 11, Nomor 2, Agustus 2006. (123-130)

Pusat Bahasa. (2008). Kamus Bahasa Indonesia. Jakarta: Departemen Pendidikan Nasional

Rahayu, A.; A.N. Bambang; dan G. Hardiman. (2013). Strategi Peningkatan Status Keberlanjutan Kota Batu sebagai Kawasan Agropolitan. Jurnal Ekosains. Surakarta: Universitas Sebelas Maret, Volume V, Nomor 1, Maret 2013. (21-34)

RKPD Kota Bitung. (2012). Rencana Kerja Pemerintah Daerah Kota Bitung Tahun 2013. Kota Bitung: BAPPEDA

Rofiq, A. (2014). Pertumbuhan Ekonomi dan Kemiskinan (Kebijakan dan Tantangan Masa Depan). Jakarta: Republika

Suharto, E. 2008. Penerapan Kebijakan Pelayanan Publik bagi Masyarakat dengan Kebutuhan Khusus. Disampaikan pada Focused Group Discussion (FGD) "Kajian Penerapan Pelayanan Khusus (Service for Customers with Special Needs) pada Sektor Pelayanan Publik”, Lembaga Administrasi Negara, Sahira Butik Hotel, Bogor 9-10 Oktober 2008. http://www.policy.hu/suharto/Naskah\%20PDF/LANPelayananPublik.pdf. (Tanggal diunduh: 5 April 2016)

Sulistiyono, A. dan M. Rustamaji. (2009). Hukum Ekonomi sebagai Panglima. Sidoarjo (Jawa Timur): Masmedia Buana Pustaka 
Tambunan, T.T.H. (2012). Perekonomian Indonesia (Kajian Teoritis dan Analisis Empiris. Jakarta: Ghalia Indonesia

Undang-Undang Nomor 25 Tahun 2007, tentang Penanaman Modal. Lembaran Negara Republik Indonesia Tahun 2009 Nomor 147. Tambahan Lembaran Negara Republik Indonesia Nomor 4727

Undang-Undang Nomor 32 Tahun 2004 tentang Pemerintahan Daerah. Lembaran Negara Republik Indonesia Tahun 2004 Nomor 125. Tambahan Lembaran Negara Republik Indonesia Nomor 4437, sebagaimana telah dua kali diubah dengan perubahan terakhir melalui Undang-Undang Nomor 12 Tahun 2008, tentang Perubahan Kedua Atas Undang-Undang Nomor 32 Tahun 2004 tentang Pemerintahan Daerah. Lembaran Negara Republik Indonesia Tahun 2008 Nomor 59. Tambahan Lembaran Negara Republik Indonesia Nomor 4844

Undang-Undang Nomor 39 Tahun 2009, tentang Kawasan Ekonomi Khusus. Lembaran Negara Republik Indonesia Tahun 2007 Nomor 67. Tambahan Lembaran Negara Republik Indonesia Nomor 5066

Yin, R.K. (2009). Studi Kasus (Desain dan Metode). Jakarta: Rajawali Pers 
